\title{
Does ambient UV-B radiation influence marine diatom-dominated microbial mats? A case study
}

\author{
Kristina Sundbäck* ${ }^{*}$ Claes Nilsson, Svante Odmark, Angela Wulff \\ Department of Marine Botany, Göteborg University, Carl Skottsbergs Gata 22b, S-413 19 Göteborg, Sweden
}

\begin{abstract}
Intact natural microbial mats collected from a shallow microtidal bay were incubated in the presence or absence of ambient ultraviolet-B radiation (UVBR) in an outdoor flow-through system for 2 and $6 \mathrm{wk}$, respectively. The microbial mats were cohesive and dominated by a large, motile diatom species, Gyrosigma balticum (Ehrenberg) Rabenhorst. The variables studied included biomass, composition of microalgae and meiofauna, bacterial biomass, pigment composition and presence of UV-absorbing compounds. Carbon assimilation and sediment oxygen microprofiles were measured as indicators of photosynthetic and respiratory activity. No significant effects were found on any of the measured variables when natural UVBR was excluded, suggesting that ambient UVBR did not exert any strong selective pressure on the particular type of microbial mat studied. Biochemical screening by UV-absorbing compounds did not appear to be of major importance for avoiding UVBR damage. Visual observations, and to some extent oxygen profiles, indicated downward migration of the dominant diatom species as a response to high light levels. This may have been an important strategy also to avoid exposure to UVBR. Thus, vertical migration of benthic diatoms appears to be a factor that should be further investigated in relation to effects of both present and enhanced levels of UVBR.
\end{abstract}

KEY WORDS: Ultraviolet radiation - Sediment - Diatoms - Light - Pigments - Meiofauna B Bacteria . Gyrosigma

\section{INTRODUCTION}

Enhanced ultraviolet-B (UVB) radiation (UVBR), due to the depletion of the stratospheric ozone layer, has lately aroused concern about the effects of UVBR on aquatic ecosystems. Hitherto, most research on UVBR effects in the marine environment has considered planktonic primary producers. Plankton algae appear to be stressed by UVBR even under normal ozonelayer conditions (Behrenfeld et al. 1993) and primary production is further decreased under the influence of the Antarctic ozone hole (Smith et al. 1992). Unialgal experiments have shown that UVBR influences several metabolic processes in microalgae (for a review see Häder 1993). Effects on microalgal productivity can also be expected through changes in bacterial activity (Herndl et al. 1993, Wetzel et al. 1995), trophic interactions (Bothwell et al. 1993, 1994) and effects on the

-E-mail: kristina.sundback@marbot.gu.se

After the first author, authors appear in alphabetical order chemical environment (Palenik et al. 1991). The fact that several interdependent effects may counteract. each other makes it difficult to predict community responses from experiments on single trophic levels, or primary producers alone (Bothwell et al. 1994, Williamson 1995).

Although shallow-water sediments are known as important nursing and feeding areas for fish and their prey (Pihl 1989 and references therein), information on the role of UVBR for sediment-associated microalgae (microphytobenthos), or other organisms of the sediment communities, is scarce. Benthic microalgae have been estimated to account for one third or more of the primary production in shallow estuaries (for references see Pinckney \& Zingmark 1993). Under favourable conditions they often form dense, cohesive microbial mats on the sediment surface (Paterson 1986, Stal \& Caumette 1994). There are several reasons why UV radiation (UVR) can be expected to influence microbenthic communities. A shallow water column allows UVR to penetrate to the sediment surface and recent 
measurements with optical microsensors have shown that UVBR levels may be high in the euphotic zone of the sediment (Garcia-Pichel \& Bebout 1996). High photosynthetic oxygen production in the euphotic zone combined with high levels of both photosynthetically active radiation (PAR) and UVR implies a potential for photochemical effects, for example through the production of free radicals (Palenik et al. 1991, GarciaPichel \& Castenholz 1994).

Effects of UVBR have been observed for microbial mats dominated by cyanobacteria (Vincent \& Quesada 1994, Bebout \& Garcia-Pichel 1995). Although cyanobacterial mats also occur in the marine environment (Yallop et al. 1994), diatom-dominated mats are the commonest type of microbial mats in marine northern-temperate areas. The high densiiy of both autotrophic and heterotrophic microorganisms in microbial mats, together with steep chemical gradients, suggests a complex response to UVBR, involving several interdependent direct and indirect effects. For microbenthic communities, the effects can also be expected to differ between different sediment types and microalgal communities, for example between motile (epipelic) algal communities of fine sediments and attached (epipsammic) algal communities of sandy sediments.

The aim of the experiments was to study how present levels of UVBR may influence a natural cohesive diatom-dominated microbial mat from a microtidal, shallow-water sediment. Estimates of response were based on biomass and composition of microalgae and meiofauna (fauna $<0.5 \mathrm{~mm}$ ), bacterial biomass, pigment composition and presence of UV-absorbing compounds, as well as carbon assimilation and sediment oxygen microprofiles.

\section{MATERIAL AND METHODS}

Study site and collection of material. The experiments were carried out at Tjärnö Marine Biological Laboratory on the west coast of Sweden $\left(58^{\circ} 52^{\prime} \mathrm{N}\right.$, $11^{\circ} 09^{\prime} \mathrm{E}$ ). This is a brackish and microtidal area with a maximum tidal amplitude of $-30 \mathrm{~cm}$ (Johannesson 1989). Sediment cores were collected with transparent tubes [inner diameter (i.d.) $68 \mathrm{~mm}$, length $150 \mathrm{~mm}$ ] from a sheltered bay at a water depth of ca $1 \mathrm{~m}$. The sediment was muddy, with a water content of $\sim 68 \%$, and covered by a brown, cohesive 2 to $3 \mathrm{~mm}$ thick microbial mat dominated by the large $(-400 \mu \mathrm{m})$ motile diatom species Gyrosigma balticum (Ehrenberg) Rabenhorst. This particular type of microbial mat, as well as the behaviour of $G$. balticum, has been previously described by Jönsson et al. (1994) and Sundbäck et al. (1996)
Experimental set-up. Two consecutive experiments were conducted during the period June to August 1994. Expt A lasted for 2 wk (June 23 to July 7), while Expt B was run for 6 wk (July 5 to August 15) The experiments were carried out in an outdoor flowthrough system, consisting of six $40 \mathrm{l}$ white square troughs $(47 \times 40 \mathrm{~cm}$, height $22 \mathrm{~cm})$ with filtered water flowing through them (cotton cartridge filters, 50 and $1 \mu \mathrm{m})$. For details of the set-up see Sundbäck et al. (1996). Water temperature during the experimental period varied between 14 and $21^{\circ} \mathrm{C}$. In both experiments 6 randomly chosen intact sediment cores were sampled for initial values. The rest of the cores were randomly distributed among the 6 troughs (i.e. 2 per trough in Expt $A$ and 1 per trough in Expt B). The 2 treatments were: no exposure to UVBR ('no IJVRR') and exposure to ambient UVBR ('natural UVBR'). The whole set of troughs was covered by UVBR-transparent Plexiglass (Esså Plast, Plexi GS OF 2458 UV, $3 \mathrm{~mm}$ ) to protect the cores from rain and seabird faeces. In addition, the no-UVBR troughs were covered with Mylar film (Dupont, Mylar-D) to screen out natural UVBR (0\% transmission at $310 \mathrm{~nm}, 50 \%$ transmission at $320 \mathrm{~nm}$ ).

Sampling and analyses. In Expt $A_{1}$ samples were taken weekly ( 3 times, incl. initial samples) and in Expt $B$, at the beginning and at the end of the experiment. At each sampling, 1 core from each of the 6 troughs, i.e. 3 from each treatment, were collected. Algal biomass, pigments, UV-absorbing compounds and oxygen profiles were measured in both experiments, while bacteria were quantified only in Expt A and meiofauna only in Expt B. Samples were taken with a sharpened circular punch (i.d. $9 \mathrm{~mm}$ ) (see Sundbäck et al. 1996). After sampling, the cores were discarded.

Oxygen profiles: Before sampling, oxygen profiles were measured with an oxygen microsensor with a guard cathode (Revsbech 1989). The measurements were made indoors at constant light $(\sim 240 \mu \mathrm{mol}$ photons $\mathrm{m}^{-2} \mathrm{~s}^{-1}$ ) from 3 halogen lamps. Oxygen concentrations were measured at vertical intervals of $100 \mu \mathrm{m}$. Three profiles per core were measured.

Microalgal biomass: For algal cell counts, 2 samples from each core were pooled. After dilution, autofluorescing algae were counted as 2 fractions (before and after ultrasonication) in an epifluorescence microscope and biovolumes were calculated and converted to carbon values. For details see Sundbäck et al. (1996)

Pigments: For pigments, 2 samples were taken from each core and analysed by high-performance liquid chromatography (HPLC) according to Wright et al. (1991) with a modification of the solvent protocol according to Kraay et al. (1992). For details see Sund- 
bäck et al. (1996). Pigment compositions are expressed as ratios to chl a.

$U \boldsymbol{V}$-absorbing compounds: Two samples from each core were pooled and extracted in 100\% methanol. Three $\mathrm{ml}$ methanol was added, the sample was shaken manually and then ultrasonicated $(35 \mathrm{kHz})$ for 3 min, followed by a $2 \mathrm{~h}$ extraction and collection of the supernatant. This procedure was repeated 3 times, pooling the consecutive supernatants. After centrifugation for $10 \mathrm{~min}$ at $1600 \times g$, the supernatant was analysed in a Shimadzu UV-160 spectrophotometer. All steps were made at room temperature in dim light. The protocol followed D. Karentz (pers. comm.), with minor modifications (e.g. 100\% methanol was used instead of $80 \%$ ).

Bacterial biomass: Three samples from each core were preserved with $0.2 \mu \mathrm{m}$ filtered $4 \%$ formaldehyde, stained with acridine orange, counted and measured (see Sundbäck et al. in press). The conversion factor

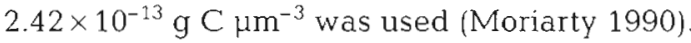

Meiofaunal biomass: Three samples from each core were pooled and preserved in $4 \%$ borax-buffered formaldehyde containing bengal rose. Meiofauna was extracted by decantation, sieved and sorted into major taxa and counted (see Sundbäck et al, 1990). Meiofaunal biomass was calculated according to Widbom (1984).

Carbon fixation: Primary productivity was measured by ${ }^{14} \mathrm{C}$-labelling. Two punched-out pieces of the microbial mat from each core were incubated separately in $25 \mathrm{ml}$ pyrex vials in the no-UVBR and natural-UVBR treatments, respectively. The Pyrex vials transmitted $\sim 25 \%$ of the radiation at $290 \mathrm{~nm}$ and $\sim 80 \%$ at $320 \mathrm{~nm}$. The samples were incubated for $2 \mathrm{~h}$ in the experimental troughs. The cohesive mat pieces remained more or less intact during the incubation. For details on further handling of ${ }^{14} \mathrm{C}$ samples, see Sundbäck et al. (1990).

Light: PAR, UVAR and UVBR were measured with an International Light (IL) 1400A photometer equipped with cosine corrected sensors (detector types SUL 033 and SUL 240). The readouts were corrected for the spectral sensitivity of the sensor and the solar and UVB tube spectra. Correction factors were derived from previous simultaneous measurements on these spectra with the IL1400A and an IL1700 radiometer.

Statistical analyses. Treatment effects were tested with a 1-factor ANOVA separately for each day. Cochran's test was used to check for homogeneity of variances (Winer et al. 1991). To test differences in sediment oxygen profiles, a nested ANOVA was run, using maximum oxygen concentration in each profile and the corresponding sediment depth as variables. Differences were accepted as significant at $p<0.05$.

\section{RESULTS}

Light conditions. The weather during Expt $A$ and during the first 4 wk of Expt B was constantly sunny. Typical PAR irradiance at midday above the water surface was 1500 to $1700 \mu \mathrm{mol} \mathrm{m} \mathrm{m}^{-2} \mathrm{~s}^{-1}$. Simultaneously measured values for UVAR were 36 to $42 \mathrm{~W} \mathrm{~m}^{-2}$, and 0.59 to $0.81 \mathrm{~W} \mathrm{~m}^{-2}$ for UVBR (280 to $320 \mathrm{~nm}$ ). During the last part of Expt $B$, the weather was more variable, but still fairly sunny.

Biomass and composition of microalgae. Microalgal biomass was initially $\sim 8 \mathrm{~g} \mathrm{C} \mathrm{m}^{-2}$ in Expt $\mathrm{A}$ (Fig. 1) and $-5 \mathrm{~g} \mathrm{C} \mathrm{m}^{-2}$ in Expt B (Fig. 2). In both experiments, but particularly in the longer one, there was a declining trend (Figs. $1 \& 2$ ) in the microalgal biomass. The algal biomass almost entirely consisted of diatoms Gyrosigma balticum, accounting for $\sim 50$ to $75 \%$ of the total. Among smaller cells, the centric diatom Paralia sulcata (Ehrenberg) Cleve dominated. Cyanobacteria (mainly Oscillatoria spp.) occasionally constituted 5 to $15 \%$, while various flagellates constituted $<1 \%$. Pigment analyses indicated that dinoflagellates and green flagellates were present (peridinin and chl b). No significant effects of excluding ambient UVBR on the total algal biomass, nor on the biomass of $G$. balticum alone, were observed. In Expt A, on Day 7 , the biomass of diatoms other than $G$. balticum appeared higher in the absence of UVBR, but this difference was not significant.

Pigments. No significant treatment effects on the amount of chl a were found. Mean values varied in Expt A between $\sim 80$ and $200 \mathrm{mg} \mathrm{chl} \mathrm{a} \mathrm{m}^{-2}$ (Fig. 1). For Expt B only final values are available $\left(-70 \mathrm{mg} \mathrm{chl}\right.$ a $\left.\mathrm{m}^{-2}\right)$ (Fig. 2). There was no effect on the ratios between measured accessory pigments and chl a (Table 1) or the ratio between the degradation products phaeophytin $a$ and phaeophorbide a to chl a (Table 2). High values of phaeophorbide $a$ at the end of Expt $B$ indicated high grazing rates.

UV-absorbing compounds. The UV-absorbing compounds in our samples were most likely mycosporinelike amino acids (MAAs), as these are widespread among algae and other marine organisms and have absorbance peaks in the range of 310 to $360 \mathrm{~nm}$ (Karentz et al. 1991). However, our absorption spectra showed very small peaks in the MAA region throughout both experiments, irrespective of treatment. Therefore, no attempt at quantification was made. A typical spectrum of a methanol extract is shown in Fig. 3.

Heterotrophic biomass. Initially, algal biomass exceeded that of bacteria by a factor of $\sim 10$ (Expt $A$; Fig. 1) and that of meiofauna by a factor of -30 (Expt B; Fig. 2). The exclusion of natural UVBR had no significant effect on either bacteria (Expt A) or meiofauna (Expt B). There was a tendency, though 

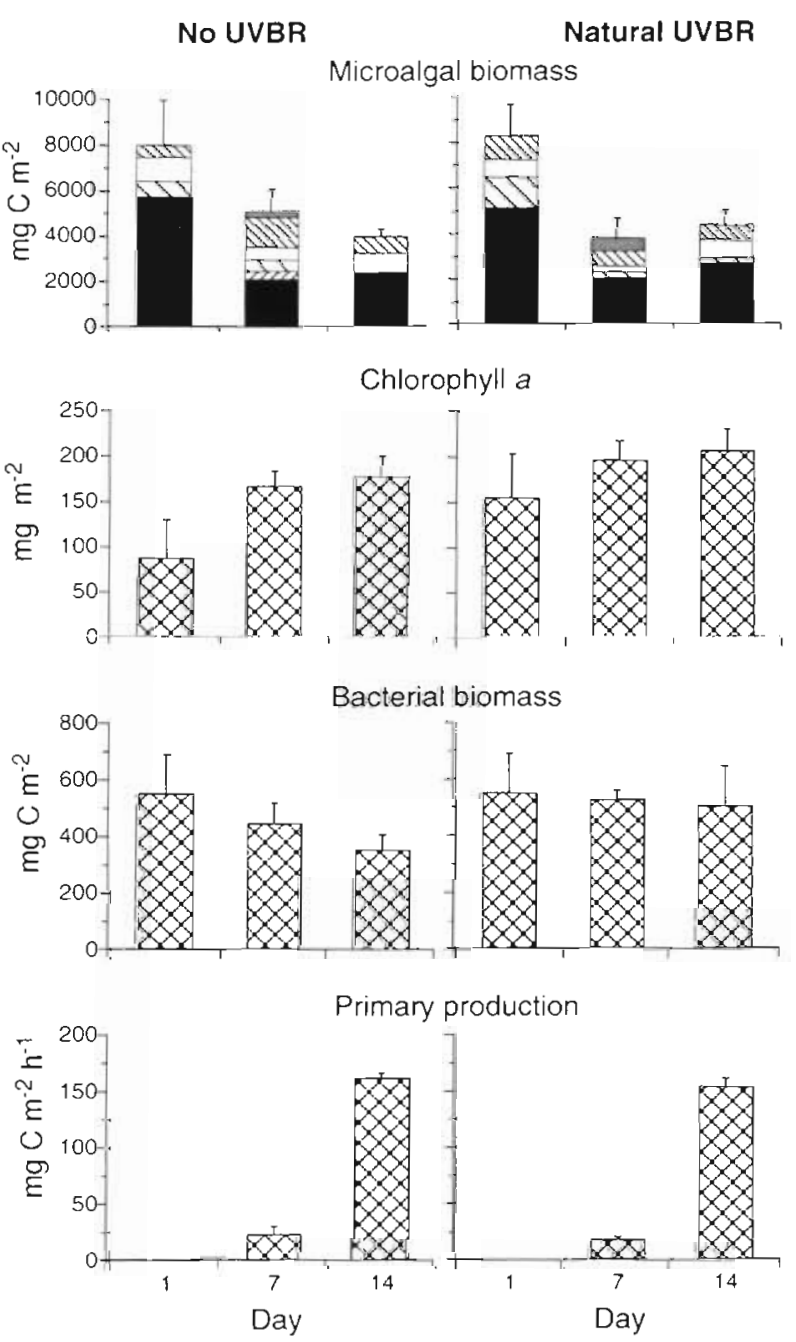

not statistically significant, of higher bacterial biomass in cores exposed to UVBR (Fig. 1). The meiofaunal biomass in Expt $B$ was dominated by nematodes, harpacticoid copepods and oligochaetes (Fig. 2). Meiofaunal biomass increased substantially during the $6 \mathrm{wk}$ long experiment. At the end, the mean ratio of algae to meiofauna was $\sim 3$ in cores exposed to UVBR and $\sim 7$ in cores shielded from UVBR. However, because of the large variation among individual cores, the difference among treatments was not significant.

Carbon assimilation. No significant difference in the carbon uptake (Expt A) between treatments was noted (Fig. 1). The low carbon uptake on Day 7 was due to the fact that the incubation was made rather late during the day.

Sediment oxygen profiles. There were no significant differences in oxygen profiles due to the exclusion of ambient UVBR (Figs. 4 \& 5). In Expt B, oxygen peaks were found at ca $150 \mu \mathrm{m}$ depth in the sediment, with maximum values of $0.9 \mathrm{mmol} \mathrm{O}_{2} \mathrm{l}^{-1}$ (Fig. 5), whereas in Expt $A$, no peaks were found at all (Fig. 4).

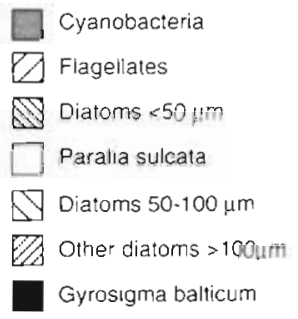

Fig. 1. Expt A. Biomass of microalgae, chlorophyll a content, biomass of bacteria, and carbon uptake of intact microbial mats shielded from UVB radiation (No UVBR) or exposed to ambient UVB radiation (Natural UVBR). Bars show mean + SE of 3 replicate cores. For microalgae, vertical lines show $S E$ for the total microalgal biomass

\section{DISCUSSION}

The results suggest that ambient UVBR did not exert any strong selective pressure on the structure of the microbial mat studied. Our experiments are among the first on the effect of UVBR on natural sediment-associated microbenthic communities, and the results should be interpreted with caution. On the other hand, our experiments should have fulfilled several requirements for drawing ecologically relevant conclusions about UVBR effects at the community level. We used intact natural sediment communities, the experiments were made outdoors under natural light conditions, and more than 1 trophic level was studied. There may, however, have been some potentially important functional parameters that responded to the exclusion of ambient UVBR that we did not detect, as we measured only a few functional variables. Moreover, although our experiments were longer than most previous experiments on the effects of UVBR in aquatic environments, they might still not have been long enough to allow for measurable structural changes through e.g. selection.

\section{Autotrophic component}

The cohesive microbial mat that we studied was entirely dominated by the autotrophic component. Thus, the community response to UVBR could be assumed to have mainly reflected the response of the dominating algal species, the large motile diatom Gyrosigma balticum. One explanation for the absence of measurable effects may have been related to the motility of this species. Previous experiments suggested that a rapid vertical migration may be an important adaptation mechanism for $G$. balticum to changed light conditions and that the species is well adapted to low light levels (Jönsson et al. 1994, Sundbäck et al 

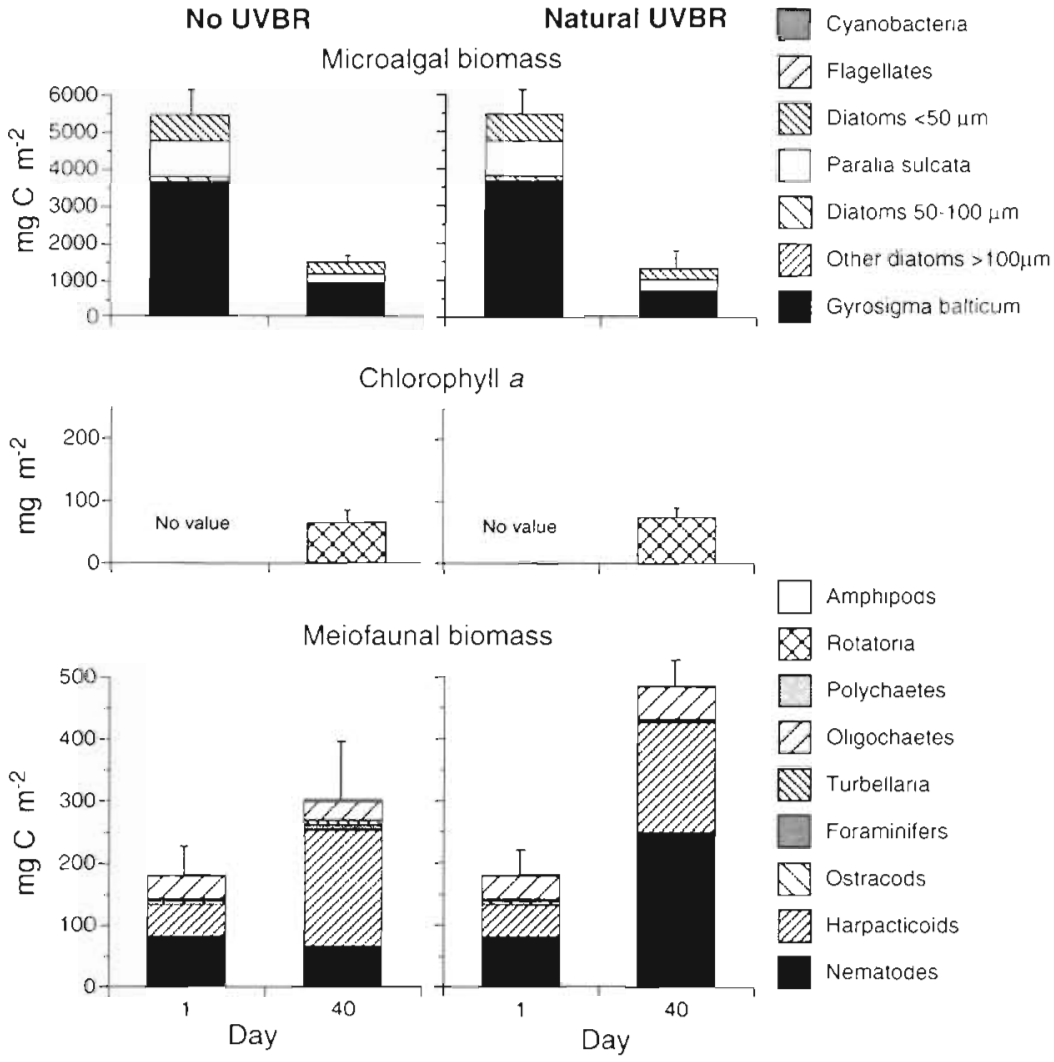

Fig. 2. Expt B. Biomass of microalgae, chlorophyll a content, and biomass of meiofauna of intact microbial mats shielded from UVB radiation (No UVBR) or exposed to ambient UVB radiation (Natural UVBR). For Day 1, bars show mean + SE of 6 replicate cores, and bars for Days 7 and 14 show mean + SE of 3 replicate cores. For meiofauna and microalgae, vertical lines show SE for the total microalgal biomass

1996). At high light levels, G. balticum cells migrate downwards, while at low light levels, they remain at the sediment surface in an upright position, giving the sediment surface a dark brown colour. The weather was sunny during both experiments, and this may have displaced the $G$. balticum population towards a greater depth in the sediment, as indicated by the light colour of the sediment surface. In this way, the algal population might also have avoided direct exposure to UVBR. The absence of peaks in the oxygen profiles in Expt A may reflect this deeper vertical position, i.e. the deep position of the algae may have prevented photosynthesis under the lower PAR fluence rates $\left(240 \mu \mathrm{mol} \mathrm{m}^{-2} \mathrm{~s}^{-1}\right)$ used during the profile measurements in the laboratory.

Although effects of UVBR exposure on pigment composition have been previously reported for both planktonic and benthic microalgae (El-Sayed et al. 1990, Garcia-Pichel \& Castenholz 1994, Quesada et al. 1995), we found no such effects. De-epoxidation of diadinoxanthin (Dd) to diatoxanthin (Dt) is known to occur in excessive light (PAR) as a protection against photooxidation (Demers et al. 1991, Arsalane et al. 1994). Deleterious effects of UVBR on the de-epoxidation process have been reported for higher plants (Pfündel et al. 1992), but we did not find any effects on the $(D d+D t) / c h l$ a ratio or on the $D t /(D d+D t)$ ratio. The fact that we took 2 to $3 \mathrm{~mm}$ deep samples (the entire depth of the mat) may have masked effects on pigments in the upper part of the mat. Garcia-Pichel \& Castenholz (1994) found UVBR effects on photosynthesis down to $0.7 \mathrm{~mm}$ in a cyanobacterial mat.

The production of MAAs does not seem to be a major UV-protection mechanism in the diatom-dominated mats we studied. This agrees with other studies (Karentz et al. 1991, Garcia-Pichel \& Castenholtz 1994, Davidson et al. 1994 and references therein), which have shown that the MAA content in diatoms appears to be orders of magnitude lower than in many other algae.

Table 1. Pigment composition expressed as ratios to chl a (mean $\pm S E, n=3$ ) in intact microbial mats exposed to (Natural UVBR) or shielded from (No UVBR) natural UVBR

\begin{tabular}{|c|c|c|c|c|c|c|}
\hline & \multicolumn{2}{|c|}{ Fucoxanthin } & \multicolumn{2}{|c|}{$\mathrm{Chl} c_{1}+\operatorname{chl} c_{2}$} & \multicolumn{2}{|c|}{ Diadinoxanthin + diatoxanthin } \\
\hline & Natural UVBR & No UVBR & Natural UVBR & No UVBR & Natural UVBR & No UVBR \\
\hline \multicolumn{7}{|l|}{ Expt A } \\
\hline Day 1 & $1.77 \pm 0.23$ & $2.13 \pm 0.51$ & $0.73 \pm 0.11$ & $0.94 \pm 0.20$ & $0.45 \pm 0.06$ & $0.46 \pm 0.12$ \\
\hline Day 7 & $1.02 \pm 0.08$ & $0.92 \pm 0.02$ & $0.41 \pm 0.04$ & $0.38 \pm 0.01$ & $0.30 \pm 0.02$ & $0.28 \pm 0.01$ \\
\hline Day 14 & $0.95 \pm 0.01$ & $0.90 \pm 0.02$ & $0.34 \pm 0.02$ & $0.33 \pm 0.05$ & $0.28 \pm 0.01$ & $0.27 \pm 0.01$ \\
\hline \multicolumn{7}{|l|}{ Expt B } \\
\hline Day 40 & $1.23 \pm 0.14$ & $1.10 \pm 0.02$ & $0.27 \pm 0.09$ & $0.28 \pm 0.08$ & $0.40 \pm 0.06$ & $0.35 \pm 0.15$ \\
\hline
\end{tabular}


Table 2. Ratios of phaeophytin a and phaeophorbide a to chl a multiplied by 1000 (mean $\pm S E, n=3$ ) in intact microbial mats exposed to (Natural UVBR) or shielded from (No UVBR) natural UVBR

\begin{tabular}{|lcccc|}
\hline & \multicolumn{2}{c}{ Phaeophythin a } & \multicolumn{2}{c|}{ Phaeophorbide a } \\
& Natural UVBR & No UVBR & Natural UVBR & No UVBR \\
\hline Expt A & & & & \\
Day 1 & $1.71 \pm 1.07$ & $0.23 \pm 0.22$ & $0.00 \pm 0.00$ & $0.01 \pm 0.01$ \\
Day 7 & $7.11 \pm 2.24$ & $4.57 \pm 0.42$ & $1.95 \pm 1.12$ & $0.00 \pm 0.00$ \\
Day 14 & $7.64 \pm 0.61$ & $6.13 \pm 1.94$ & $2.78 \pm 0.56$ & $1.88 \pm 0.98$ \\
Expt B & & & & \\
Day 40 & $15.0 \pm 4.0$ & $12.4 \pm 1.0$ & $14.7 \pm 4.1$ & $6.6 \pm 1.5$ \\
\hline
\end{tabular}

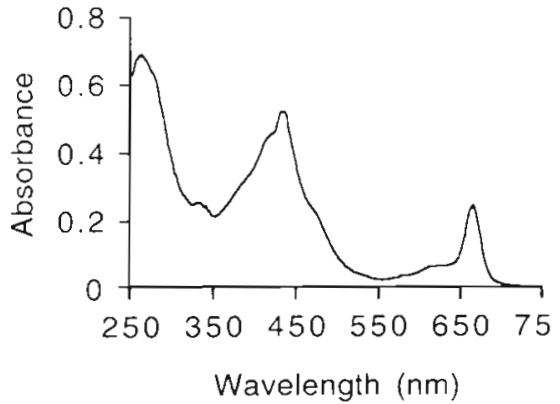

Fig. 3. A typical spectrum of a methanol extract showing the small peak for UV-absorbing compounds at $-336 \mathrm{~nm}$
Differential sensitivity of algal taxa, coupled to selectıon, has been suggested to aiter the composition of algal communities in response to UVBR (Worrest et al
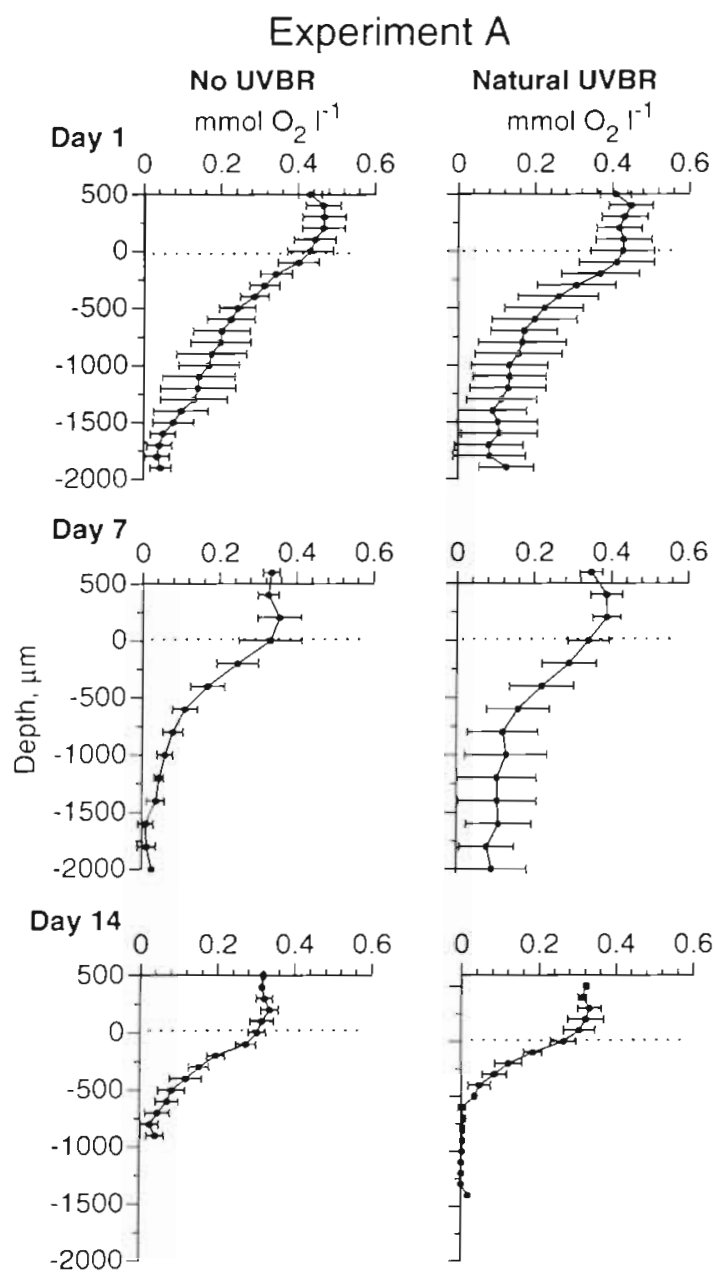

Fig. 4. Oxygen profiles of intact microbial mats in Expt A that have been shielded from UVB radiation (No UVBR) or exposed to ambient UVB radiation (Natural UVBR). Each profile shows mean $\pm \mathrm{SE}$ from 3 replicate cores. Dotted line: surface of the microbial mat
1981, Villafañe et al. 1995, Davidson et al. 1996, Wängbety ét àl. 1996). Bothrivell et al. (1993, 1994) showod that exposure to ambient UVBR influenced the species succession of an attached freshwater diatom community colonizing an artificial substratum, both directly and via effects on grazers. Taking into account measured growth rates of natural epipelic diatom populations (specific growth rates 0.06 to 0.3 ; Admiraal et al 1982, Gould \& Gallagher 1990), structural changes should have been possible to detect in the course of our experiments. On the other hand, we studied an already

\section{Experiment $\mathrm{B}$}

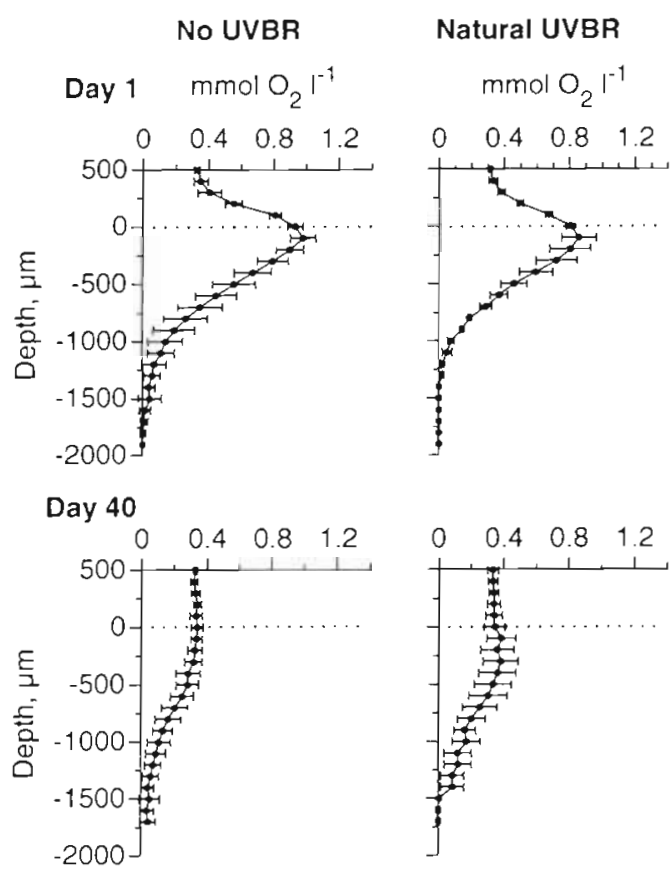

Fig. 5. Oxygen profiles of intact microbial mats in Expt $B$ that have been shielded from UVB radiation (No UVBR) or exposed to ambient UVB radiation (Natural UVBR). Each profile shows mean $\pm \mathrm{SE}$ from 3 replicate cores. Dotted line: surface of the microbial mat 
established, thick natural diatom mat with no net growth. Therefore, the effects of removing a presumed selective pressure (UVBR) could not have been as easily revealed as in a rapidly growing algal community under succession. This, together with the fact that the dominating algae apparently avoided strong light by vertical migration, may explain why no changes in the community composition were found. However, we do not know which spectral part induced the migration. On the other hand, we did not make any detailed analysis at the species level for diatoms $<50 \mu \mathrm{m}$, among which there are usually several attached species, unable to avoid UVBR exposure by movement.

Most UV-related studies on phytoplankton have shown that primary production decreases under exposure to UVBR even at ambient levels (for a review see Vincent \& Roy 1993). However, we found no significant effects on carbon fixation. As the punched-out mat pieces remained more or less intact during the incubation, downward migration could most probably have occurred under these conditions, provided that it was induced by radiation penetrating the incubation vials.

In summary, we found no significant effects of the ambient UVBR on the autotrophic component of the mat. We did not find any evidence for biochemical screening, whereas visual observations, and to some extent oxygen profiles, suggest that vertical migration may have been a mechanism to avoid strong light, and thereby also UVBR damage. There are also other results supporting the absence of effects of ambient UVBR on benthic diatoms. In a laboratory study, Peletier et al. (1995) found that none of 8 intertidal diatom species showed reduced growth except for UVBR levels much above the natural level.

\section{Heterotrophic components}

The main effects of UVBR on food webs need not primarily be through primary producers ('bottom-up control') but can also be mediated through the consumer level ('top-down') (Williamson 1995). For example, Bothwell et al. $(1993,1994)$ found that initial negative effects on freshwater periphytic diatom communities by ambient UVBR were later outweighed by a deleterious effect on herbivores. In Expt B, the ratio between algae and meiofauna changed with time, but not with treatment (Fig. 2). This, together with high values of phaeophorbide $a$ at the end of the experiment, indicated a high grazing pressure by meiofauna. Measurements of meiofaunal grazing rates in sandy sediments have suggested that meiofauna may occasionally limit microalgal biomass (Sundbäck et al. in press). If meiofaunal activity was affected by the exclusion of UVBR in our $6 \mathrm{wk}$ experiment, there should have been a measurable effect, considering the growth rates and generation times of meiofauna (Nilsson 1992).

We did not find any significant UVBR effects on bacterial biomass, although there was an indication of reduced biomass when natural UVBR was excluded. However, we did not measure bacterial productivity, which does not need to be correlated with bacterial biomass (van Duyl \& Kop 1990, Nilsson et al. 1991). Bacteria in aquatic systems can be affected by UVBR in at least 2 ways. Firstly, bacteria are known to be sensitive to UVBR (Herndl et al, 1993). Secondly, UVBR enhances photochemical breakdown of high-molecular-weight organic compounds, thereby stimulating bacterial growth (Lindell et al. 1995, Wetzel et al. 1995). On the other hand, sediment bacteria may be less substrate-limited (Sundbäck et al. 1990, Nilsson et al. 1991) than bacteria in the water column, particularly in the organically rich sediment that we studied. Thus, stimulation through photochemical breakdown may not be of major importance for sediment bacteria, although this hypothesis remains to be tested.

\section{Conclusions}

The results suggest that ambient UVBR does not exert a strong selective pressure on the structure of a cohesive microbial mat dominated by motile diatoms. However, it is doubtful whether the general conclusion can be drawn that ambient UVBR does not influence diatom-dominated microbial mats in shallow waters. Moreover, we do not know whether our results are applicable for tidal conditions. To understand the ecological role of UVBR for microbenthic communities and their possible response to an enhanced level of UVBR, 2 requirements need to be fulfilled in future experiments. Firstly, UVR and PAR levels within the sediment must be measured, as well as the vertical distribution of organisms in response to these levels. Secondly, different types of benthic communities should be studied under time periods long enough to allow changes through natural selection, trophic interactions and other long-term mechanisms.

Acknowledgements. We thank Dr Benno Jönsson for oxygen microsensor measurements, Dr Lena Carlson for help during the field work and Ms Hanna Wigforss for counting bacteria. Financial support was provided by research grants from the Swedish Environmental Protection Agency, the Swedish Natural Science Research Council, the Futura Foundation, and the Marine Research Centre at Göteborg University. Additional support was given by the funds of Wilhelm and Martina Lundgren, Captain Carl Stenholm, and Helge Ax:son Johnsson. We thank 4 anonymous referees for constructive comments. 


\section{LITERATURE CITED}

Admiraal $W$, Peletier $H$, Zomer $H(1982)$ Observations and experiments on the population dynamics of epipelic diatoms from an estuarine mudflat. Estuar Coast Shelf Sci 14: $471-487$

Arsalane W, Rousseau B, Duval JC (1994) Influence of the pool size of the xanthophyll cycle on the effects of light stress in a diatom: competition between photoprotection and photoinhibition. Photochem Photobiol 60:237-243

Bebout BM, Garcia-Pichel F (1995) UVB-induced vertical migrations of cyanobacteria in a microbial mat. Appl Environ Microbiol 61:4215-4222

Behrenfeld M, Hardy J, Gucinski H, Hanneman A, Lee $H$ II, Wones A (1993) Effects of ultraviolet-B radiation on primary production along latitudinal transects in the South Pacific Ocean. Mar Environ Res 35:349-363

Bothwell ML, Sherbot DMJ, Pollock CM (1994) Ecosystem response to solar ultraviolet- $B$ radiation: influence of trophic-level interactions. Science 265:97-100

Bothwell ML, Sherbot DMJ, Roberge AC, Daley RJ (1993) Influence of natural ultraviolet radiation on lotic periphytic diatom community growth, biomass accrual, and species composition: short-term versus long-term effects. J Phycol 29:24-35

Davidson AT, Bramich D, Marchant HJ, McMinn A (1994) Effects of UV-B irradiation on growth and survival of Antarctic marine diatoms. Mar Biol 119:507-515

Davidson AT, Marchant HJ, de la Mare WK (1996) Natural UVB exposure changes the species composition of Antarctic phytoplankton in mixed culture. Aquat Microb Ecol 10 299-305

Demers S, Roy S, Gagnon R, Vignault C (1991) Rapid lightinduced changes in cell fluorescence and in xanthophyllcycle pigments of Alexandrium excavatum (Dinophyceae) and Thalassiosira pseudonana (Bacillariophyceae): a photoprotection mechanism. Mar Ecol Prog Ser 76:185-193

El-Sayed SZ, Stephens FC, Bidigare RR, Ondrusek ME (1990) Effects of ultraviolet radiation on Antarctic marine phytoplankton. In: Kerry KR, Hempel G (eds) Antarctic ecosystems. Ecological change and conservation. SpringerVerlag, Berlin, p 379-385

Garcia-Pichel F, Bebout BM (1996) Penetration of ultraviolet radiation into shallow water sediments: high exposure for photosynthetic communities. Mar Ecol Prog Ser 131 $257-262$

Garcia-Pichel F, Castenholz RW (1994) On the significance of solar ultraviolet radiation for the ecology of microbial mats. In: Stal LJ, Caumette P (eds) Microbial mats. NATO ASI Series G: Ecological sciences, Vol 35. Springer-Verlag, Berlin, p 77-84

Gould DM, Gallagher ED (1990) Field measurement of specific growth rate, biomass, and primary production of benthic diatoms of Savin Hill Cove, Boston. Limnol Oceanogr 35:1757-1770

Häder DP (1993) Risks of enhanced solar ultraviolet radiation for aquatic ecosystems. In: Round FE, Chapman DJ (eds) Progress in phycological research, Vol 9. Biopress Ltd, Bristol, p 1-45

Herndl GJ, Müller-Niklas G. Frick J (1993) Major role of ultraviolet-B in controlling bacterioplankton growth in the surface layer of the ocean. Nature 361:717-719

Johannesson K (1989) The bare zone of Swedish rocky shores: why is it there? Oikos 54:77-86

Jönsson B, Sundbäck K, Nilsson C (1994) An upright life-form of an epipelic motile diatom: on the behaviour of Gyrosigma balticum. Eur J Phycol 29:11-15
Karentz D, McEuen FS, Land MC, Dunlap WC (1991) Survey of mycosporine-like amino acid compounds in Antarctic marine organisms: potential protection from ultraviolet exposure. Mar Biol 108:157-1.66

Kraay GW, Zapata M, Veldhuis MJW (1992) Separation of chlorophylls $c_{1}, c_{2}$, and $c_{3}$ of marine phytoplankton by reversed-phase-C18-high-performance liquid chromatography. J Phycol 28:708-712

Lindell MJ, Granélí W, Tranvik LJ (1995) Enhanced bacterial growth in response to photochemical transformation of dissolved organic matter. Limnol Oceanogr 40:195-199

Moriarty DJW (1990) Techniques for estimating bacterial growth rates and production of biomass in aquatic environments. Meth Microbiol 22:211-234

Nilsson P (1992) The role of meiofauna in a marine shallowwater sediment community. Doctoral thesis, Goteborg University

Nilsson $P$, Jönsson $B$, Lindström Swanberg $I$, Sundbäck $K$ (1991) Response of a marine shallow-water sediment system to an increased load of inorganic nutrients. Mar Ecol Prog Ser 71:275-290

Palenik B, Price NM, Morel FMM (1991) Potential effects of UV-B on the chemical environment of marine organisms: $a$ review. Environ Poll 70:117-130

Paterson DM (1986) The migratory behaviour of diatom assemblages in a laboratory tidal micro-ecosystem examined by low temperature scanning electron microscopy. Diat Res 1:227-239

Peletier H, Gieskes WWC, Buma AGJ (1995) UVBR-resistance of benthic diatom isolates of tidal flats in the Dutch Wadden Sea. In: Veen A, Buma AGJ, Gieskes WWC, van Liere L (eds) Effects of ozone related UV-B enhancement on aquatic ecosystems. RIVM report 731054002, Rjjksinstituut voor volkgezondheid en milieu, Bilthoven, p 59-66

Pfündel E, Pan RS, Dilley RA (1992) Inhibition of violaxanthin deepoxidation by ultraviolet-B radiation in isolated chloroplasts and intact leaves. Plant Physiol 98:1372-1380

Pihl L. (1989) Abundance, biomass and production of juvenile flatfish in southeastern Kattegat. Neth J Sea Res 24:69-81

Pinckney J, Zingmark RG (1993) Biomass and production of benthic microalgal communities in estuarine habitats. Estuaries 16:887-897

Quesada A, Mouget JL, Vincent WF (1995) Growth of Antarctic cyanobacteria under ultraviolet radiation: UVA counteracts UVB inhibition. J Phycol 31:142-248

Revsbech NP (1989) An oxygen microelectrode with a guard cathode. Limnol Oceanogr 34:474-478

Smith RC, Prézelin BB, Baker KS, Bidigare RR, Boucher NP, Coley T, Karentz D, MacIntyre S, Matlick HA, Menzies D, Ondrusek M. Wan Z, Waters KJ (1992) Ozone depletion: ultraviolet radiation and phytoplankton biology in Antarctic waters. Science 255:952-959

Stal LJ, Caumette P (1994) Microbial mats. Structure, development and environmental significance. NATO ASI Series G: Ecological sciences, Vol 35. Springer-Verlag, Berlin

Sundbäck K, Carlson L, Nilsson C, Jönsson B, Wulff A, Odmark S (1996) Response of benthic microbial mats to drifting green algal mats. Aquat Microb Ecol 10:195-208

Sundbäck K, Jönsson B, Nilsson P, Lindström I (1990) Impact of accumulating drifting macroalgae on a shallow-water sediment system: an experimental study. Mar Ecol Prog Ser 58:261-274

Sundbäck K, Nilsson P, Nilsson C, Jönsson B (ın press) Balance between autotrophic and heterotrophic components and processes in microbenthic communities of sandy sediments: a field study. Estuar Coast Shelf Sci 43 
van Duyl FC, Kop AJ (1990) Seasonal patterns of bacterial production and biomass in intertidal sediments of the western Dutch Wadden Sea. Mar Ecol Prog Ser 59:249-261

Villafane VE, Helbling EW, Holm-Hansen O, Chalker BE (1995) Acclimatization of Antarctic natural phytoplankton assemblages when exposed to solar ultraviolet radiation. J Plankton Res 17:2295-2306

Vincent WF, Quesada A (1994) Ultraviolet radiation effects on cyanobacteria: implications for Antarctic microbial ecosystems. In: Weiler CS, Penhale PA (eds) Ultraviolet radiation in Antarctica: measurements and biological effects. Antarctic Research Serjes, Vol 62. American Geophysical Union, Washington, DC, p 111-124

Vincent WF, Roy $\mathrm{S}$ (1993) Solar ultraviolet-B radiation and aquatic primary production: damage, protection, and recovery. Environ Rev 1:1-12

Wängberg SA, Selmer JS, Gustavson K (1996) Effects of UV-B radiation on biomass and composition in marine phytoplankton communities. Sci Mar 60(Suppl 1):81-88

Wetzel RG, Hatcher PG, Bianchi TS (1995) Natural photolysis by ultraviolet irradiance of recalcitrant dissolved organic

Responsible Subject Editor: T. H. Blackburn, Aarhus, Denmark matter to simple substrates for rapid bacterial metabolism. Limnol Oceanogr 40:1369-1380

Widbom B (1984) Determination of average individual dry weights and ash-free dry weights in different sieve fractions of marine meiofauna. Mar Biol 75:101-109

Williamson CE (1995) What role does UV-B radiation play in freshwater ecosystems? Limnol Oceanogr 40:386-392

Winer BJ, Brown DR, Michels KM (1991) Statistical principles in experimental design. McGraw-Hill Inc, New York

Worrest RC, Thomson BE, van Dyke H (1981) Impact of UV-B radiation upon estuarine microcosms. Photochem Photobiol 33:861-867

Wright SW, Jeffrey SW, Mantoura RFC, Llewellyn CA, Bjørnlan DT, Repeta D, Welschmeyer N (1991) Improved HPLC method for the analysis of chlorophylls and carotenoids from marine phytoplankton. Mar Ecol Prog Ser 77: 183-196

Yallop ML, de Winder B, Paterson DM, Stal LJ (1994) Comparative structure, primary production and biogenic stabilization of cohesive and non-cohesive marine sediments inhabited by microphytobenthos. Estuar Coast Shelf Sci $39: 565-582$

Manuscript first received: May 29, 1996

Revised version accepted: August 30, 1996 